\title{
Effect of Vitamin D Repletion by Medication Versus Sunlight-Exposure on the Testicular Functions of Vitamin D Deficient Rats
}

\author{
MAHMOUD M.A. ABULMEATY, M.D.*; ALAA I. ALI, M.D.**; MOHAMED F. EL-SADEK, Ph.D.*** and \\ EBTESAM M. IBRAHIM, M.D.*
}

The Departments of Medical Physiology* and Clinical Pharmacology**, Faculty of Medicine, Zagazig University and The Department of Nutrition and Food Science, Faculty of Home Economics, Helwan University***

\begin{abstract}
Background: The causal relationship between Vitamin D (VD) and gonadal function is still under-investigated especially the impact of VD repletion on the testicular structure and function. The sunlight exposure as a natural source of VD and VD supplementation are the fundamental remedies for VD repletion during deficiency conditions.

Aim of Study: To compare the efficacy of VD medications versus sunlight exposure on the testicular functions and histology in adult rats.

Material and Methods: Sixty weaned male albino rats $(103.12 \pm 11.67 \mathrm{~g})$ were fed either a synthetic balanced formula with normal VD level (group A, n=30), or fed a customized synthetic diet with traces of VD (group B, $n=30$ ) for 6 weeks. Rats in both groups were further subdivided into three subgroups ( $\mathrm{n}=10$ each): Oil-treated control (subgroup A-I and BI), VD3 treated (subgroup A-II and B-II) which were given a dose of $75 \mathrm{~g} \mathrm{CDD}_{3} /$ rat every other day via a feeding tube, and the sun-exposed (subgroup A-III and B-III) which were exposed daily to the direct sunlight from $9 \mathrm{am}$ to $1 \mathrm{pm}$. Plasma 25-hydroxyvitamin D (25OHVD) and testosterone (T) were measured by ELISA kits. After euthanasia, the testes were isolated, and the number of spermatids per each gram of testicular tissue and Daily Sperm Production (DSP) were calculated. Furthermore, testicular sections were stained and examined under a light microscope.
\end{abstract}

Results: VD deficient rats showed a marked reduction of $\mathrm{T}$ when compared with normal control $(p<0.001)$, positive correlation with plasma 25OHVD $(r=0.739, p<0.05)$ and histologically, there were a reduction in the Leydig cell mass and degenerative changes in all levels of the spermatogenesis. Repletion of VD by the supplement (subgroup B-II) showed a better increment of the plasma $\mathrm{T}$ than in sun-exposed rats. Sunlight produced a T-stimulatory effect without a concomitant rise of the 25OHVD but the Ca level was normalized in subgroup B-III (vs. A-I, $p>0.05$ ). The spermatid count per $g$ of testis and DSP were significantly improved in both subgroups (B-II and B-III) when compared with deficient controls $(p<0.05)$, with no difference between both modalities of VD repletion. Microscopically, a marked improvement of germinal epithelium and all stages of spermatogenesis, together with

Correspondence to: Dr. Mahmoud M.A. Abulmeaty, E-Mail: dr.abulmeaty@gmail.com an increase in Leydig cell counts were detected in subgroup B-II rather than in subgroup B-III.

Conclusions: VD supplementation could improve plasma $\mathrm{T}$ levels and structure of the testes better than sunlight exposure. Sunlight exposure improved T level by a non-VD-dependant mechanism, most probably by normalization of the Ca level. Future research should investigate the underlying mechanisms.

Key Words: Testicular function - Testosterone - Vitamin D - Sun exposure.

\section{Introduction}

VITAMIN D (VD) has a well-known effect on calcium and phosphate homeostasis [1], but the physiological contributions of this fat-soluble vitamin include many other processes e.g. immune system modulation [2], cardiovascular function regulation [3], and control of many inflammatory reactions [4]. As the VD is a fat-soluble vitamin, it mediates its effect through an intracellular receptor in approximately 30 different tissues [5]. The presence of VD receptors in testicular tissues ensures that VD has a role in the male reproductive functions [6]. VD receptor-knockout mice presented with hypogonadism, low sperm count and motility, and microscopic abnormalities of testicular tissues [7]. These findings are intensified with the results of both human and animal studies which proved that a low plasma level of VD was associated with a higher risk of hypogonadism [8] . Sood et al., [9] reported that the effect of VD supplementation on the testicular function based on sperm count and Leydig cell mass was dose-dependent. However, the effect of VD repletion on testosterone (T) levels especially in regard to the mechanisms, the adverse effects and the outcomes in cases with hypogonadism is still under investigation [10]

Vitamin D presents in many sources especially dairy products and fatty fishes in addition to its 
endogenous biosynthesis in the skin with the exposure to Ultraviolet-B rays (UVB) from sunlight [11]. About ninety percent of VD requirements should be synthesized in the skin after exposure to UVB making a basis of the description of VD as a sunshine vitamin [12]. The active form of VD metabolite 1,25 dihydroxycholecalciferol $(1,25-$ $\mathrm{OH} 2 \mathrm{VD}$ ) is not an exclusive renal product but it is released from other organs such as prostate, colon, skin, and osteoblasts to act by autocrine or paracrine mechanisms for regulating many cellular functions such as cell growth [13]. Strict sun protection and indoor lifestyle cause VD deficiency in some risk groups leading to susceptibility to many non-skeletal diseases such as autoimmune diseases, hypertension, cardiovascular disease and cancer [14]. Repletion of VD stores with sunlight exposure and its effects on testicular function is still under-investigated. In light of the above data, the aim of this study is to investigate the efficacy of VD supplementation versus sunlight exposure on the testicular function and structure in a VD deficient rat model.

\section{Material and Methods}

Animals: A total of sixty males, locally available albino rats (91-115g), from the Animal House in the Faculty of Pharmacy, Zagazig University were used. The animals were kept for 1 week for habituation in clean standard cages in the Animal House in the Faculty of Medicine of Zagazig University in the temperature range of $22 \pm 2^{\circ} \mathrm{C}$ and the normal light/dark cycle. The care and use of rats were in according to the guidelines of the Institute of Laboratory Animal Resources, 1996 [15] . The experimental protocol was done between August and December 2017 after approved by the Institutional Review Board (IRB) and the Ethics Committee of the Faculty of Medicine, Zagazig University.

Groups: Animals were randomly subdivided into:

- Group A (n=30): Rats were fed a synthetic balanced formula (formed in the Nutrition and Food Science Department, Faculty of Home Economics, Helwan University) with protein $18.1 \%$, fat $7.1 \%$, carbohydrate $59.3 \%$, Calcium $5.1 \mathrm{~g} / \mathrm{kg}$, and the VD (VD $3=1000 \mathrm{IU} / \mathrm{kg}$ ) for 6 weeks. These rats were further subdivided into three equal subgroups:

- Subgroup A-I: As a vehicle-treated VD-sufficient control, where the rats were given $0.66 \mathrm{ml}$ of canola oil via a feeding tube every other day for 2 weeks.

- Subgroup A-II: Which was given a dose 75 /ral (0.66ml) of Vitamin D3 (Vi-De 3, Novartis Egypt)
[16] plus $0.66 \mathrm{ml}$ of canola oil via a feeding tube every other day for 2 weeks.

-Subgroup A-III: Which was exposed to the direct sunlight for 4 hours starting from 9:00 to 13:00, 6 days per week for 2 weeks in September 2017. No forms of sun-screening/protection were applied during the sun exposure [17]

- Group B $(n=30)$ : Was fed a customized synthetic VD-deficient diet (formed in the Nutrition and Food Science Department, Faculty of Home Economics, Helwan University) with protein $18.1 \%$, fat $7.1 \%$, carbohydrate $59.3 \%$, Calcium $5.1 \mathrm{~g} / \mathrm{kg}$, and Vitamin D (VD) 0-50IU/kg [18], for 6 weeks then further subdivided into three equal subgroups:

- Subgroup B-I: Which served as a vehicle-treated VD deficient control.

- Subgroup B-II: VD-treated subgroup which was given the same dose (75 from the same product used in subgroup A-II, by the same frequency, duration, and method.

- Subgroup B-III: The sun-exposed subgroup which was exposed daily to the sun in the same manner and same period as the subgroup A-III.

Blood and tissue sampling: After overnight fasting, the rats were anesthetized with $35 \mathrm{mg} / \mathrm{kg}$ of sodium pentobarbital [19] to obtain a blood sample via cardiac puncture. In addition, the right testis was isolated according to the procedures described by Idris [20] for counting the daily sperm production and the left testis excision for histopathological examination. The right testis was immediately frozen in plain tubes, while the left testis was reserved in formalin $10 \%$ solution.

Biochemical analysis: Plasma 25-hydroxy Vitamin D (25OHVD) and T were measured as follow:

1- Plasma 25OHVD by using rat ELISA kits [21] catalog no MBS288530 (Mybiosource USA), according to the protocol described by the manufacturer.

2- Total plasma $\mathrm{T}$ by using rat ELISA kits [22] catalog no MBS282195 (Mybiosource USA), according to the method described by the manufacturer protocol.

3- Total calcium $(\mathrm{Ca})$ level by using a colorimetric assay kit [21] catalog no CA7941 (Randox UK) for Hitachi 717 device (Hitachi, Japan).

Daily sperm production: To get the total number of spermatids per testis, a frozen right testis was warmed at $25^{\circ} \mathrm{C}$ and tunicae albuginea were opened 
then the parenchyma was weighed and homogenized for $0.5 \mathrm{~min}$ in $5 \mathrm{ml}$ of a normal saline which included 0.5\% Triton X-100 (Sigma-Aldrich). After 5-fold dilution, 20 home sample was placed into a hemocytometer slide (Neubauer, China) and the spermatids were counted under a microscope at X400 magnification against the squares of RBCs. The resulting number was divided by the weight of the testis, to determine the number of spermatids per each gram (g) of the testis. The Daily Sperm Production (DSP) was calculated by dividing the total count of spermatids by 6.1 (the number of days these spermatids were present in the seminiferous epithelium) [23] the total spermatids count was obtained by multiplying the count of right testis by two to compensate for the left one which was used for the histopathological examination [24].

Histological examination: The dissected left testis was kept in a $10 \%$ formalin solution for fixation. The tissue was washed, then dehydrated through ascending grades of alcohol, cleared in xylene and embedded in paraffin blocks. Sections 4-5 ickness was cut and stained with hematoxylin and eosin then was examined under the light microscope at 200X magnification. The microscopic description is done for all samples and they are graded according to the following criteria as mild, moderate and severe hypospermatogenesis [25]:

- Mild: Low number of germ cells in less than $30 \%$ of the seminiferous tubules.

- Moderate: Low number of germ cells in $30 \%$ to $60 \%$ of the seminiferous tubules.

- Severe: Low number of germ cells in more than $60 \%$ of the seminiferous tubules.

\section{Statistical analysis:}

The data were presented as the mean \pm SD. Statistical significance. An ANOVA with a post hoc test (LSD) was used to analyze the differences in multiple comparisons among subgroups. Pearson's correlation coefficient was done to test the association between plasma 25OHVD and all studied parameters in all subgroups. $p$-values $<0.05$ were considered to be significant. For the statistical analyses, SPSS Version 23 for Windows (SPSS Inc. Chicago, IL, USA) was used.

\section{Results}

Effect of VD deficiency on plasma $T$ level and structure of the testis:

After feeding the rats the synthetic diets for 6 weeks, the body weights were changed from 103.12 $\pm 11.67 \mathrm{~g}$ to $185.67 \pm 12.19 \mathrm{~g}$ with no significant differences among different subgroups. The VDdeficient control rats showed a marked reduction of plasma T, Ca levels, spermatid count and the DSP in comparison to VD-sufficient control ( $p$ $<0.001$ ) (Table 1). Histology showed a remarkable reduction in the Leydig cell mass and degenerative changes in the germinal epithelium in which a moderate decrease in population of the spermatogenic germ cells with poor spermatogenesis order was apparent Fig. (1). Additionally, plasma 25OHVD showed a significant positive correlation with T level, spermatid count and the DSP ( $r=0.739$, $0.824,0.816$, respectively, $p<0.05$ ) (Table 2 ).

\section{Effect of VD repletion on the studied parameters:}

In comparison to subgroup B-I, VD-supplemented/deficient subgroup (B-II) showed marked increase in plasma $\mathrm{T}$ level much more than that in subgroup B-III $(7.08 \pm 0.97 \mathrm{ng} / \mathrm{ml}$, and $2.64 \pm 0.85 \mathrm{ng} /$ $\mathrm{ml}$ respectively versus $0.80 \pm 0.20 \mathrm{ng} / \mathrm{ml}$ ). In other words, T level in subgroup B-III was nearly returned back to normal level (none-significant vs. subgroup A-I), while in subgroup B-II it became more than double that of the normal control. Interestingly, sun exposure failed to raise the plasma 25OHVD level, but the Ca level get normalized. The pharmacological dose of VD normalized 25OHVD as well as Ca levels. The spermatid count per gram of testis and daily sperm production were significantly improved when compared with deficient controls (subgroup B-I) (Table 1). No difference was existed between both modalities of VD repletion (subgroup B-III vs subgroup B-II, $p>0.05$ ) regarding the daily sperm production, while the mean of spermatid count was significantly lower in sun-exposed rats. Regarding VD-sufficient rats, VD supplementation significantly increased plasma T level (A-II vs. A-I, $p<0.05$ ) without a concomitant significant rise in plasma 25OHVD. Furthermore, the sun exposure failed to give any significant rise in the levels of all measured parameters.

The correlation study showed a significant positive correlation between 25OHVD and T level in subgroups A-I, B-I, and B-II (Table 2). Like Tlevel, the pharmacological repletion of VD showed a significant positive correlation of 25OHVD with spermatid count and the daily sperm production. This association did not exist in VD-sufficient rats which were supplemented with VD. In the other hand, the sun exposure for VD-deficient rats showed a significant positive correlation between 25OHVD and spermatid count as well as daily sperm production, this was not the case in VDsufficient subgroup (subgroup A-III). 
After VD repletion, microscopic examination of the selected regions of interest showed marked improvement of the germinal epithelium and all stages of spermatogenesis. It improved from moderate to mild hypospermatogenesis, together with an increase in Leydig cell count in subgroup B-II rather than in subgroup B-III Fig. (2). The VD supplementation or sun-exposure in rats with normal VD (subgroup A-II and A-III) produced similar changes in comparison with the sufficient control especially as regarding the number of germ cells along with lumen filled with mature spermatids Fig. (3).
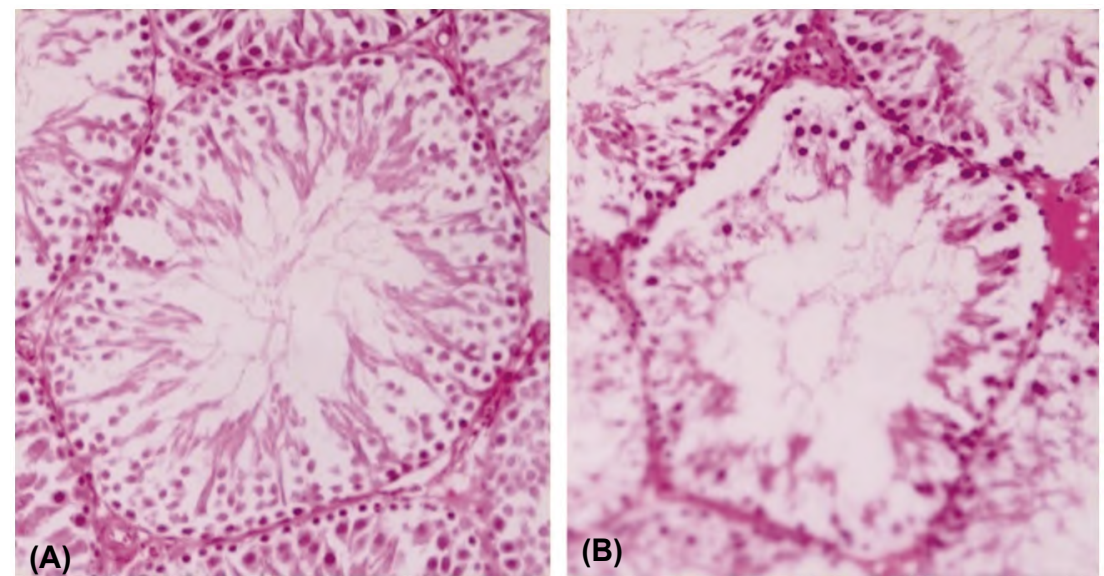

Fig. (1): Testicular sections from Vitamin D sufficient control (group A-I) (A) and Vitamin D deficient control (group B-I) rats (B) after 6 weeks of VD deficient diet.
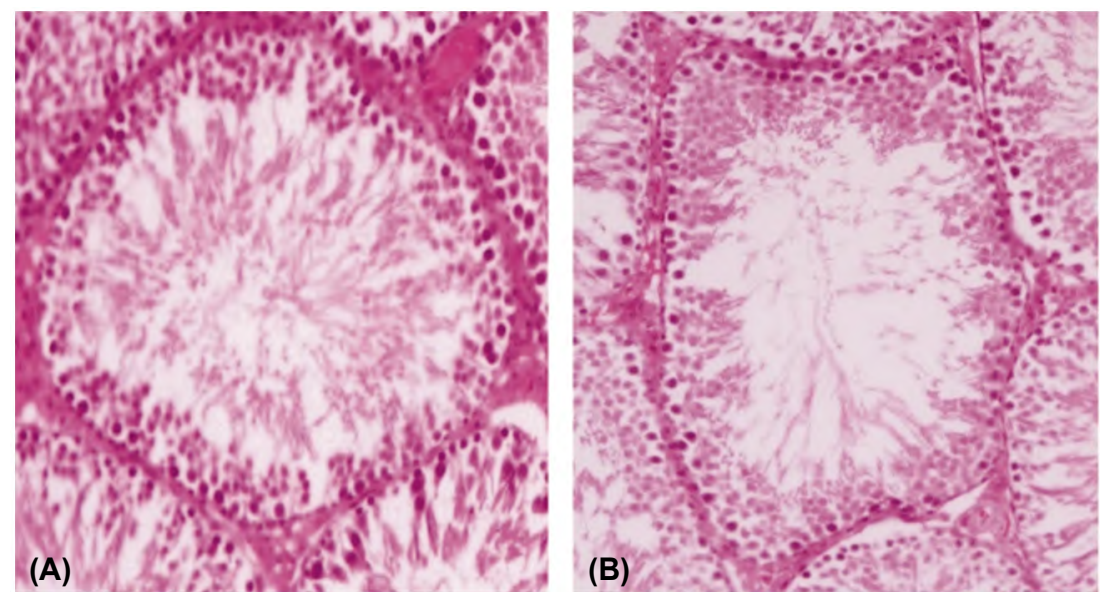

Fig. (2): Testicular sections from Vitamin D treated (group B-II) (A) and sun-exposed (group B-III) rats (B) after 2 weeks of VD repletion.
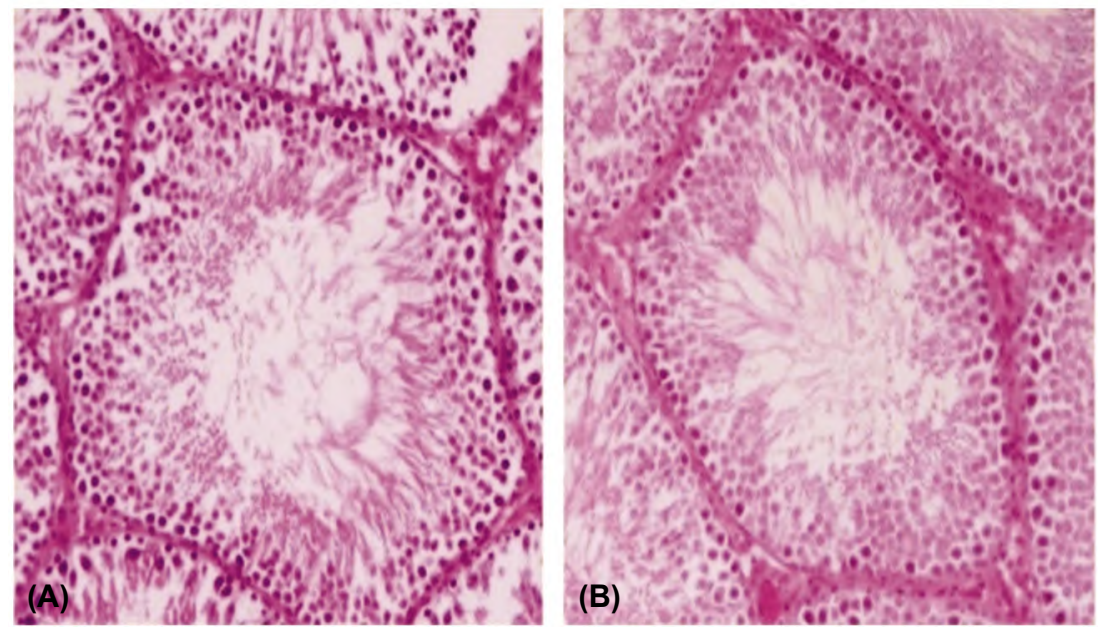

Fig. (3): Testicular sections from Vitamin D supplemented/ sufficient (group A-II) (A), and sun-exposed/ sufficient (group A-III) rats (B) after 2 weeks of intervention. 
Table (1): Statistical analysis of plasma T, 25(OH)-VD, spermatid count and daily sperm production in the studied subgroups.

\begin{tabular}{|c|c|c|c|c|c|c|}
\hline \multirow{2}{*}{$\begin{array}{l}\text { Studied } \\
\text { parameters }\end{array}$} & \multicolumn{3}{|c|}{ Group A } & \multicolumn{3}{|c|}{ Group B } \\
\hline & $\begin{array}{l}\text { Subgroup A-I } \\
\quad(\mathrm{N}=10)\end{array}$ & $\begin{array}{l}\text { Subgroup A-II } \\
(\mathrm{N}=10)\end{array}$ & $\begin{array}{l}\text { Subgroup A-III } \\
\qquad(\mathrm{N}=10)\end{array}$ & $\begin{array}{l}\text { Subgroup B-I } \\
\qquad(\mathrm{N}=10)\end{array}$ & $\begin{array}{c}\text { Subgroup B-II } \\
\quad(\mathrm{N}=10)\end{array}$ & $\begin{array}{l}\text { Subgroup B-III } \\
\qquad(\mathrm{N}=10)\end{array}$ \\
\hline $\begin{array}{l}\text { - Testosterone } \\
(\mathrm{ng} / \mathrm{ml})\end{array}$ & $3.11 \pm 0.72$ & $\begin{array}{l}4.39 \pm 0.85 \\
p<0.05 \mathrm{a}\end{array}$ & $\begin{array}{l}3.58 \pm 0.87 \\
p>0.05 \mathrm{a} \\
p>0.05 \mathrm{c}\end{array}$ & $\begin{array}{l}0.80 \pm 0.20 \\
p<0.001^{\mathbf{a}}\end{array}$ & $\begin{array}{l}7.08 \pm 0.97 \\
p<0.001 \text { a } \\
p<0.001 \text { b }\end{array}$ & $\begin{array}{l}2.64 \pm 0.85 \\
p>0.05 \mathbf{a} \\
p<0.001 \mathbf{b , d}\end{array}$ \\
\hline $\begin{array}{l}\cdot 25(\mathrm{OH})-\mathrm{VD} \\
(\mathrm{ng} / \mathrm{ml})\end{array}$ & $33.50 \pm 5.03$ & $\begin{array}{l}39.06 \pm 6.45 \\
p>0.05^{\mathrm{a}}\end{array}$ & $\begin{array}{l}34.23 \pm 6.35 \\
p>0.05 \mathbf{a} \\
p>0.05 \mathrm{c}\end{array}$ & $\begin{array}{l}15.88 \pm 5.77 \\
p<0.001^{\mathrm{a}}\end{array}$ & $\begin{array}{l}32.31 \pm 4.81 \\
p>0.05 \mathbf{a} \\
p<0.001^{\mathbf{b}}\end{array}$ & $\begin{array}{l}14.19 \pm 2.72 \\
p<0.001^{\mathbf{a}} \\
p>0.05^{\mathbf{b}} \\
p<0.001^{\mathbf{d}}\end{array}$ \\
\hline $\begin{array}{l}\text { - Calcium } \\
\text { (mg/dl) }\end{array}$ & $10.12 \pm 1.46$ & $\begin{array}{l}11.03 \pm 1.60 \\
p>0.05^{\mathrm{a}}\end{array}$ & $\begin{array}{l}11.51 \pm 2.14 \\
p>0.05^{\mathbf{a}} \\
p>0.05 \mathrm{c}\end{array}$ & $\begin{array}{l}5.10 \pm 0.86 \\
p<0.001 \mathrm{a}\end{array}$ & $\begin{array}{l}7.91 \pm 1.09 \\
p<0.05^{\mathbf{a}} \\
p<0.05^{\mathbf{b}}\end{array}$ & $\begin{array}{l}9.62 \pm 0.87 \\
p>0.05^{\mathrm{a}} \\
p<0.001^{\mathrm{b}} \\
p<0.05 \mathrm{~d}\end{array}$ \\
\hline $\begin{array}{l}\text { - Spermatid } \\
\text { count }(\mathrm{X} 10 \% \mathrm{~g} \\
\text { of testis) }\end{array}$ & $74.41 \pm 2.56$ & $\begin{array}{l}75.60 \pm 3.69 \\
p>0.05^{a}\end{array}$ & $\begin{array}{l}76.40 \pm 4.09 \\
p>0.05 \mathrm{a} \\
p>0.05 \mathrm{c}\end{array}$ & $\begin{array}{l}50.81 \pm 6.95 \\
p<0.001 \mathbf{a}\end{array}$ & $\begin{array}{l}75.61 \pm 4.55 \\
p>0.05 \mathbf{a} \\
p<0.001 \mathbf{b}\end{array}$ & $\begin{array}{l}60.45 \pm 5.04 \\
p>0.05^{\mathbf{a}} \\
p<0.001^{\mathbf{b}} \\
p<0.05 \mathbf{d}\end{array}$ \\
\hline $\begin{array}{l}\text { - Daily sperm } \\
\text { produzction } \\
\left(\mathrm{X} 10^{5}\right)\end{array}$ & $11.83 \pm 2.04$ & $\begin{array}{l}11.43 \pm 2.62 \\
p>0.05^{\mathrm{a}}\end{array}$ & $\begin{array}{l}12.59 \pm 2.72 \\
p>0.05^{\mathrm{a}} \\
p>0.05 \mathrm{c}\end{array}$ & $\begin{array}{l}8.36 \pm 1.12 \\
p<0.05 \mathrm{a}\end{array}$ & $\begin{array}{l}12.00 \pm 1.73 \\
p>0.05^{\mathbf{a}} \\
p<0.05^{b}\end{array}$ & $\begin{array}{l}11.48 \pm 2.32 \\
p>0.05^{\mathbf{a}} \\
p<0.05^{\mathbf{b}} \\
p>0.05 \mathbf{d}\end{array}$ \\
\hline
\end{tabular}

$a: p$-value versus the sufficient control (subgroup A-I).

c: $p$-value versus the pharmacological VD-treated/sufficient (subgroup A-II) $b$ : $p$-value versus the vitamin D-deficient control (subgroup B-I). d: $p$-value versus the pharmacological VD-treated/deficient (subgroup B-II).

Table (2): The correlation between 25OHVD and the testicular parameters.

\begin{tabular}{|c|c|c|c|c|c|c|}
\hline \multirow[b]{2}{*}{$\begin{array}{l}\text { Studied } \\
\text { parameters }\end{array}$} & \multicolumn{3}{|c|}{ Group A } & \multicolumn{3}{|c|}{ Group B } \\
\hline & $\begin{array}{c}\text { Subgroup } \\
\text { A-I } \\
(\mathrm{N}=10)\end{array}$ & $\begin{array}{c}\text { Subgroup } \\
\text { A-II } \\
(\mathrm{N}=10)\end{array}$ & $\begin{array}{c}\text { Subgroup } \\
\text { A-III } \\
(\mathrm{N}=10)\end{array}$ & $\begin{array}{c}\text { Subgroup } \\
\text { B-I } \\
(\mathrm{N}=10)\end{array}$ & $\begin{array}{c}\text { Subgroup } \\
\text { B-II } \\
(\mathrm{N}=10)\end{array}$ & $\begin{array}{c}\text { Subgroup } \\
\text { B-III } \\
(\mathrm{N}=10)\end{array}$ \\
\hline \multicolumn{7}{|l|}{$\begin{array}{l}\text { - Testosterone } \\
\text { (ng/ml): }\end{array}$} \\
\hline $\begin{array}{l}r \\
p \text {-value }\end{array}$ & $\begin{array}{l}0.847 \\
p<0.05\end{array}$ & $\begin{array}{l}0.610 \\
p>0.05\end{array}$ & $\begin{array}{l}0.453 \\
p>0.05\end{array}$ & $\begin{array}{l}0.739 \\
p<0.05\end{array}$ & $\begin{array}{l}0.799 \\
p<0.05\end{array}$ & $\begin{array}{l}0.713 \\
p>0.05\end{array}$ \\
\hline \multicolumn{7}{|c|}{$\begin{array}{l}\text { - Spermatid } \\
\text { count }\left(X 10^{5} / \mathrm{g}\right. \\
\text { of testis): }\end{array}$} \\
\hline \multicolumn{7}{|l|}{$\begin{array}{l}\text { - Daily sperm } \\
\text { production } \\
\left(X 10^{5}\right):\end{array}$} \\
\hline $\begin{array}{l}r \\
p \text {-value }\end{array}$ & $\begin{array}{l}0.817 \\
p<0.05\end{array}$ & $\begin{array}{l}0.665 \\
p>0.05\end{array}$ & $\begin{array}{l}0.571 \\
p>0.05\end{array}$ & $\begin{array}{l}0.816 \\
p<0.05\end{array}$ & $\begin{array}{l}0.792 \\
p<0.05\end{array}$ & $\begin{array}{l}0.912 \\
p<0.05\end{array}$ \\
\hline
\end{tabular}

\section{Discussion}

Vitamin D is a fat-soluble vitamin which plays an essential role not only as regarding the metabolism but also in different body systems especially cardiovascular, nervous and immune system [26] The effect of VD on the integrity of the reproductive process especially in males since the discovery of
VD receptors in testis is an attractive point for investigations. Blomberg Jensen et al., [6] showed that the deficiency of VD is associated with reduced serum level of $\mathrm{T}$ with the subsequent negative influence of spermatogenesis and sperm count. These results coincide with the results of our study which showed a significant reduction of $\mathrm{T}$ level in VD deficient subgroup in comparison to the treated 
subgroup which was associated with histological changes in the form of a remarkable reduction in the Leydig cell mass and degenerative changes in the germinal epithelium.

The normal physiological process of dermal synthesis of Vitamin D necessitates variable durations of sun exposure depending upon daytime, altitude, season, cloud cover, pollution, the degree of skin pigmentation and clothes [27]. To overcome the potential deficiency, VD supplementation is used worldwide as a prophylactic and therapeutic agent especially by risk groups as children, pregnant and elderly [28]. The comparison between the effect of sun exposure and VD supplementation is an interesting area of research. Chel et al., [29] claimed that UVB is as effective as vitamin D supplementation in geriatric patients, while Wicherts and colleagues [30] reported that VD supplementation is more effective than sun exposure in treatment of VD deficiency in immigrants, moreover Hajhashemi et al., [31] showed that VD supplementation is superior to UVB exposure in pregnant women with VD deficiency. The result of the present study showed also a significant difference in the plasma 25OHVD, as an indicator for VD level, between VD-supplemented subgroup in comparison to the sun-exposed subgroup of VDdeficient rats. Whereby the plasma level of 25OHVD in VD-supplemented-subgroup showed no significant difference with the other subgroups which was fed with an adequate amount of VD (VD3=1000IU $/ \mathrm{kg}$ ). In contrast, the plasma level of 25OHVD in the sun-exposed and VD-deficient rats (subgroup B-III) was markedly low with no significant difference with the subgroup B-I. It is well known that adequate sun exposure is a mandatory factor for the production of sufficient amount of VD but the sun exposure alone doesn't guarantee a normal plasma level of cholecalciferol, because the skin hair (in rats) or clothes (in human) and other environmental conditions play also a critical role [30].

The previous research work demonstrated a positive association between plasma level of 25OHVD and T level, where VD-supplementations succeeded to raise both total and free $\mathrm{T}$ level in a group of healthy overweight men undergoing a weight reduction program [32] or through a crosssectional study investigated and identified the positive association between $\mathrm{T}$ level and plasma level of 25OHVD in patients with prostate cancer [33] and in a cross-sectional study analyzed and proved the positive correlation between plasma level of 25OHVD and T level in Korean men [34] All these reports are in accordance with the result of the present study. The result of our study showed a significant increase in $\mathrm{T}$ level in all subgroups in comparison to the subgroup B-I (VD-deficient control). The rise in plasma level of $\mathrm{T}$ by the subgroup B-II (VD-supplemented subgroup) was 8 folds higher than subgroup B-I. The marked elevation of $\mathrm{T}$ level by the pharmacological form of VD in the subgroup B-II and A-II could be explained by Hofer et al., [35] who reported that the primary human testicular cells which were treated with $1,25(\mathrm{OH})_{2} \mathrm{VD} 3$ showed a marked increase in $\mathrm{T}$ production and enhancement in the expression of mRNA of enzymes involved in $\mathrm{T}$ production and its precursors. Moreover, Hussain et al., [36] returned the T-stimulatory effect of VD to; a) maintenance of the levels of Luteinizing Hormone (LH), and Follicle Stimulating Hormone (FSH), b) up-regulating superoxide dismutase, glutathione peroxidase, and the antioxidant pool, and c) down-regulating malondialdehyde, inducible nitric oxide synthase species and nitric oxide.

Interestingly, although the plasma level of 25OHVD in the subgroup B-III was insignificant in comparison to the subgroup B-I, the plasma level of T was 3 folded higher. Moreover, this Tstimulatory effect of UVB was existed in Vitamin D sufficient rats (subgroup A-III) but in an insignificant manner. The direct ability of UVB to modulate sex steroids in a fish model was studied by Mitchell et al., [37] they found that a single exposure to a sublethal dose of the UVB significantly decreased all free sex steroids, while increased 11-ketotestosterone in addition to enhancement of androgen receptor (AR a) expression in the skin. This direct action could do a permissive effect on the stimulatory effect of Vitamin D on T secretion. This could put a basis for the seasonal variation in T level with the summer-associated higher level of androgens [38]. On the other hand, Koukouna et al., [39] reported that light exposure succeeded to raise the serum level of $\mathrm{T}$ in a group of patients suffering from hypoactive sexual disorders. The researcher claimed that light exposure leads to pineal body inhibition which is responsible for melatonin production. Melatonin itself would induce prolactin secretion which inhibits $\mathrm{T}$ production. However, the suggested mechanism of Tstimulatory effect of sunlight in the concomitant low 25OHVD level relay on normalization of the $\mathrm{Ca}$ level which might be induced by a direct effect of the UVB. The sunlight could affect the permeability of cell membranes with enhanced availability of calcium ions [40]. Lerchbaum et al., [10] reported that the repletion of calcium alone in Vitamin Ddeficient rats was capable of restoring the fertility. 
These findings might explain our results regarding the elevation of T level in subgroup B-III and intensify the assumption of non-VD possible mechanisms.

More than $95 \%$ of $\mathrm{T}$ is produced by Leydig cells in the testis. The synthesis and secretion of $\mathrm{T}$ are under the control of the hypothalamicpituitary-testicular axis. Hypothalamus produces gonadotropin-releasing hormone $(\mathrm{GnRH})$ which stimulates the pituitary gland to secrete FSH and LH. Finally, these latter hormones (mainly LH) stimulate the testis to produce $T$ [41]. This basic pathway is regulated through different factors e.g. age, exercise, nutrients (vitamins), medications and sleep and seasonal variations [42]. For example, Biswas et al., [43] reported that rats which were continuously exposed to the light produced higher levels of GnRH, FSH, LH, and T. He explained these results through the effect of alpha $2 \mathrm{u}$-globulin which stimulates the production of pituitary gonadotropins with subsequent elevation of $\mathrm{T}$ level. Furthermore, the fat-soluble VD can penetrate easily cell membranes and bind to specific intracellular receptors (VDR). The VD-receptor complex interacts with the Retinoid X Receptor (RXR). This heterocomplex of VDR-RXR acts as a transcription factor which then translocates into the nucleus to bind to and activate Vitamin DResponsive Elements (VDREs) in the promoter region of target genes [44]

Concerning the daily sperm production and spermatid count per gram of testis, the results of the present study exhibited a significant reduction in subgroup B-I. This reduction was significantly improved after VD repletion, with no difference between both modalities of VD repletion. These results are in accordance with the results of Gonçalves et al., [45] who demonstrate that VD 3 stimulates a plasma membrane-bound enzyme Gamma-Glutamyl Transpeptidase (GGT) in Sertoli cells through a nongenomic mechanism of action involving Protein Kinase A (PKA) activation with subsequent increase in glucose uptake, lactate dehydrogenase activity and lactate production these metabolic processes enhance the Sertoli cells' contribution to germ cells nutrition and improve spermatogenesis.

Discrepancies in the results of the current study and the previous research work might be attributed to the differences in the studied designs and species, administration of different doses or forms of VD, the routs of administration of these medications and the duration of treatment or sunlight exposure.

\section{Conclusion:}

Taken together, VD plays an essential role in the integrity of testicular function especially spermatogenesis and $\mathrm{T}$ production. Regarding the way of replenishment, VD-supplementation represents a more reliable method than sun light exposure which is usually affected by many environmental factors.

\section{Acknowledgment:}

To Dr. Mai M. Abd El-Wahab, Pathology Department, Faculty of Medicine, Zagazig University for help in performing the histopathology.

\section{References}

1- HEANEY R.P., MURAD M.H. and WEAVER C.M.: Evaluation, treatment, and prevention of vitamin D deficiency: An Endocrine Society clinical practice guideline. J. Clin. Endocrinol. Metab., 96: 1911-30, 2011.

2- IKEMOTO Y., KURODA K., NAKAGAWA K., OCHIAI A., OZAKI R., MURAKAMI K., JINUSHI M., MATSUMOTO A., SUGIYAMA R. and TAKEDA S.: Vitamin D Regulates Maternal T-Helper Cytokine Production in Infertile Women. Nutrients, 10 (7): 1-10, 2018.

3- JUDD S.E. and TANGPRICHA V.: Vitamin D Deficiency and Risk for cardiovascular disease. Am. J. Med. Sci., 117: 503-11, 2010.

4- DALL'ARA F., CUTOLO M., ANDREOLI L., TINCANI A. and PAOLINO S.: Vitamin D and systemic lupus erythematous: A review of immunological and clinical aspects. Clin. Exp. Rheumatol., 36 (1): 153-62, 2018.

5- ZITTERMANN A.: Vitamin D in preventive medicine: Are we ignoring the evidence? Br. J. Nutr., 89: 552-72, 2003.

6- BLOMBERG JENSEN M., NIELSEN J.E., JØRGENSEN A., RAJERT-De MEYTS E., KRISTENSEN D.M. and JØRGENSEN N.: Vitamin D receptor and Vitamin D metabolizing enzymes are expressed in the human male reproductive tract. Hum. Reprod., 25: 1303-11, 2010.

7- BOUILLON R., CARMELIET G., VERLINDEN L., VANETTEN E., VERSTUYF A., LUDERER H.F., LIEBEN L., MATHIEU C. and DEMAY M.: Vitamin D and human health: Lessons from Vitamin D receptor null mice. Endocrine Reviews, 29: 726-76, 2008.

8- WANG N., HAN B., LI Q., CHEN Y., XIA F., DONGPING LIN D., JENSEN M.D. and LU Y.: Vitamin D is associated with testosterone and hypogonadism in Chinese men: Results from a cross-sectional SPECT-China study. Reprod. Biol. Endocrinol., 13: 74-81, 2015.

9- SOOD S., REGHUNANDANAN R., REGHUNANDANAN V., MARYA R.K. and SINGH P.I.: Effect of Vitamin $D$ repletion on testicular function in Vitamin D-deficient rats. Ann. Nutr. Metab., 39 (2): 95-103, 1995.

10- LERCHBAUM E. and OBERMAYER-PIETSCH B.: Mechanisms in endocrinology: Vitamin D and fertility: A systematic review. Eur. J. Endocrinol., 166: 765-78, 2012. 
11- WEHR E., PILZ S., BOEHM B.O., MÄRZ W. and OBERMAYER-PIETSCH B.: Association of Vitamin D status with serum androgen levels in men. Clin. Endocrinol. Oxf., 73: 243-8, 2010.

12- NAIR R. and MASEEH A.: Vitamin D: The "sunshine" vitamin. J. Pharmacol. Pharmacother., 3 (2): 118-26, 2012.

13- REICHRATH J.: The challenge resulting from positive and negative effects of sunlight: How much solar UV exposure is appropriate to balance between risks of Vitamin D deficiency and skin cancer? Prog. Biophys. Mol. Biol., 92 (1): 9-16, 2006.

14- HASSAN-SMITH Z.K., HEWISON M. and GITTOES N.J.: Effect of Vitamin D deficiency in developed countries. Br. Med. Bull., 9: 1-11, 2017.

15- Institute of Laboratory Animal Resources, Commision on Life Sciences and National Research Council: Guide for the care and use of laboratory animals, 8 thEdition. National academy press, Washington D.C., 21-55, 1996.

16- BROUWER D.A.J., VAN-BEEK J., FENVERDA H., BRUGMAN A.M., VAN-DER KLIS F.R.M., VAN-DER HEIDEN H.J. and MUSKIET F.A.J.: Rat adipose tissue rapidly accumulates and slowly releases an orallyadministered high Vitamin D dose. British Journal of Nutrition, 79: 527-32, 1998.

17- IYANDA A.A.: Exposure to Sun Rays: An Investigation of Serum Micronutrient Status in Wistar Rats. Asian Journal of Biomedical and Pharmaceutical Sciences, 04 (30): 1-5, 2014

18- FLEET J.C., GLINIK C., ZHANG Z., XUE Y., SMITH K.B., McCREEDY R. and ADEDOKUN S.A.: Serum Metabolite Profiles and Target Tissue Gene Expression Define the Effect of Cholecalciferol Intake on Calcium Metabolism in Rats and Mice. J. Nutr., 138: 1114-20, 2008.

19- TAKAI S., JIN D., SAKONJO H., TAKUBO T. and NAKANISHI T.: Significance of the Vascular Concentration of Angiotensin II-Receptor Blockers on the Mechanism of Lowering Blood Pressure in Spontaneously Hypertensive Rats. J. Pharmacol. Sci., 123: 371-9, 2013.

20- IDRIS A.I.: Ovariectomy/orchidectomy in rodents. Methods Mol. Biol., 816: 545-51, 2012.

21- LETAVEMIER E., VERRIER C., GOUSSARD F., PEREZ J., HUGUET L., HAYMANN J., BAUD L., BAZIN D. and DAUDON M.: Calcium and Vitamin D have a synergistic role in a rat model of kidney stone disease. Kidney International, 90 (4): 809-17, 2016.

22- SHUAI B., SHEN L., YANG Y.P., XIE J., ZHOU P.Q., LI H., GUO X.F., ZHAO J. and WU J.L.: Effects of Chinese kidney-tonifying drugs on bone mineral density (BMD), biomechanics, 25-hydroxy vitamin D3 and 1,25dihydroxy Vitamin D 3 of ovariectomized osteoporosis rats. Zhongguo. Gu. Shang, 21 (11): 850-3, 2008.

23- SEIFI M., EZZATI B., SAEDI S. and HEDAYATI M. The Effect of Ovariectomy and Orchiectomy on Orthodontic Tooth Movement and Root Resorption in Wistar Rats. J. Dent. (Shiraz), 16 (4): 302-9, 2015.

24- CHIOCA L.R., MULLER J.C, BOARETO A., ANDEATINI R. and DALSENTER P.R.: Sodium fluoride does not alter sperm production or sperm morphology in rats. Braz. Arch. Biol. Technol., 55 (2): 257-62, 2012.
25- ROBB G.W., AMANN R.P. and KILLIAN G.J.: Daily sperm production and epididymal sperm reverses of pubertal and adult rats. J. Reprod. Fertil., 54: 103-7, 1978.

26- MEO S.A., ARIF M., RASHIED S., KHAN M.M., VOHRA M. S., USMANI A.M., IMRAN M.B. and Al-DREES A.M.: Hypospermatogenesis and spermatozoa maturation arrest in rats induced by mobile phone radiation. J. Coll. Physicians Surg. Pak., 21 (5): 262-5, 2011.

27- NORMAN A.W., BISHOP J.E., BULA C.M., OLIVERA C.J., MIZWICKI M.T., ZANELLO L.P., ISHIDA H. and OKAMURA W.H.: Molecular tools for study of genomic and rapid signal transduction responses initiated by $1 \alpha$ $25(\mathrm{OH})$ 2-vitamin D3 . Steroids, 67 (6): 457-66, 2002.

28- DAWODU A. and AKINBI H.: Vitamin D nutrition in pregnancy: Current opinion. Int. J. Women's Health, 5: 333-43, 2013

29- HOLICK M.F.: Vitamin d deficiency. N. Engl. J. Med., 357: 266-81, 2007.

30- CJEL V.G., OOMS M.E., POPP-SNIJDERS C., PAVEL S., SCHOTHORST A.A., MEULEMANS C.C. and LIPS P.: Ultraviolet irradiation corrects Vitamin D deficiency and suppresses secondary hyperparathyroidism in the elderly. J. Bone Miner. Res., 13: 1238-42, 1998.

31- WICHERTS I.S., BOEKE A.J.P., VAN DER MEER I.M., VAN SCHOOR N.M., KNOL D.L. and LIPS P.: Sunlight exposure or Vitamin D supplementation for vitamin ddeficient non-western immigrants: A randomized clinical trial. Osteoporos. Int., 22: 873-82, 2011.

32- HAJHASHEMI M., KHORSANDI A. and HAGHOLLAHI F.: Comparison of sun exposure versus Vitamin D supplementation for pregnant women with Vitamin D deficiency. J. Matern. Fetal Neonatal. Med., 28: 1-6, 2017.

33- PILZ S., FRISCH S., KOERTKE H., KUHN J., DREIER J., OBERMAYER-PIETSCH B., WEHR E. and ZITTERMANN A.: Effect of Vitamin D supplementation on testosterone levels in men. Horm. Metab. Res., 43: 2235, 2011.

34- NIMPTSCH K., PLATZ E.A., WILLETT W.C. and GIOVANNUCCI E.: Association between plasma 25-OH Vitamin D and testosterone levels in men. Clin. Endocrinol. (Oxf)., 77 (1): 106-12, 2012.

35- TAK Y.J., LEE J.G., KIM Y.J., PARK N., KIM S.S., LEE S., CHO B.M., KONG E.H., JUNG D.W. and YI Y.H.: Serum 25-hydroxyvitamin D levels and testosterone deficiency in middle-aged Korean men: A cross-sectional study. Asian J. Androl., 17 (2): 324-8, 2015

36- HOFER D., MÜNZKER J., SCHWETZ V., ULBING M., HUTZ K., STIEGLER P.H., ZIGEUNER R., PIEBER T.R, MÜLLER H. and OBERMAYER-PIETSCH B.: Testicular Synthesis and Vitamin D Action. The Journal of Clinical Endocrinology \& Metabolism, 99 (10): 376673, 2014.

37- HUSSAIN F., MALIK A., QURESHI M.S., IMRAN M., WAQUAR S., SHAFIQUE H., RANA Z., THU H.E. and HUSSAIN Z.: Homeostatic relevance of Vitamin D in maintaining male fertility in human: Down-regulation of oxidative stress and up-regulation of anti-oxidative defense and steroidal hormones. Asian Pac. J. Reprod., 7: 56-61, 2018 . 
38- MITCHELL D.L., FERNANDEZ A.A., GARCIA R., PANIKER L., LIN K., HANNINEN A., ZIGELSKY K., May M, NUTTALL M, LO H., PERSON M.D. and EARLEY R.: Acute exposure to Ultraviolet-B radiation modulates sex steroid hormones and receptor expression in the skin and may contribute to the sex-bias of melanoma in a fish model. Pigment Cell Melanoma Res., 27 (3): 408-17, 2014.

39- SMITH R.P., COWARD R.M., KOVAC J.R. and LIPSHULTZ L.I.: The evidence for seasonal variations of testosterone in men. Maturitas, 74 (3): 208-12, 2013.

40- KOUKOUNA D., LETIZIA BOSSINI L., CASOLARO I. and FAGIOLINI A.: Light therapy as a treatment for sexual dysfunction; focus on testosterone levels. European Neuropsychopharmacology, 26 (2): S606, 2016.

41- TIAN X.Q., CHEN T.C., MATSUOKA L.Y., WORTSMAN J. and HOLICK M.F.: Kinetic and thermodynamic studies of the conversion of previtamin D 3 to Vitamin D3 in human skin. J. Biol. Chem., 268: 14888-92, 1993.

42- PAYNE A.H. and O'ShAUGHNESSY P.: "Structure, function, and regulation of steroidogenic enzymes in the Leydig cell". In PAYNE A.H., HARDY M.P. and RUS-
SELL L.D. Leydig Cell. Vienna [Il]: Cache River Press, 260-85, 1996.

43- HUHTANIEMI I.: Late-onset hypogonadism: Current concepts and controversies of pathogenesis, diagnosis and treatment. Asian Journal of Andrology, 16 (2): 192202, 2014.

44- BISWAS N.M., BISWAS R., BISWAS N.M. and MANDAL L.H.: Effect of continuous light on spermatogenesis and testicular steroidogenesis in rats: Possible involvement of alpha $2 \mathrm{u}$-globulin. Nepal Med. Coll. J., 15 (1): 62-4, 2013.

45- HAUSSLER M.R., JURUTKA P.W., MIZWICKI M. and NORMAN A.W.: Vitamin D receptor (VDR)-mediated actions of $1 \mathrm{a}, 25(\mathrm{OH})(2)$ vitamin $\mathrm{D}(3)$ : Genomic and nongenomic mechanisms. Best Pract. Res. Clin. Endocrinol. Metab., 25 (4): 543-59, 2011.

46- GONCALVES R., ZAMONER A., ZANATTA L., ZANATTA A.P., REMOR A.P., SCHEFFER D., LATINIA., REGINA F. and SILVA M.B.: 1,25(OH)2 Vitamin D 3 signalling on immature rat Sertoli cells: gamma-glutamyl transpeptidase and glucose metabolism. J. Cell Commun. Signal., 11 (3): 233-43, 2017.

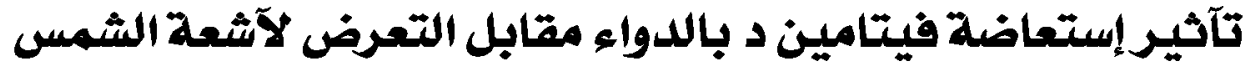

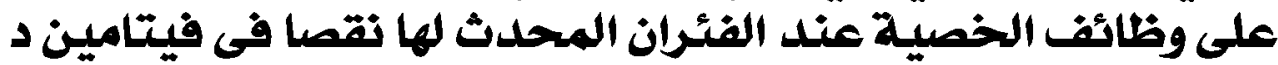

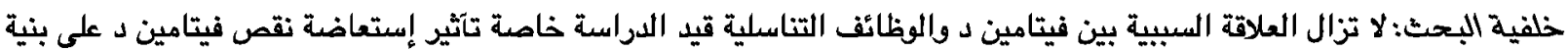

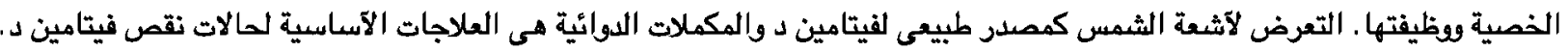

الهدف من البحث:تهدف هذه الدراسة إلى التحقق فى فعالية آدوية فيتامين د مقابل التعرض لآشعة الثمس على وظائف وتركيب الخصية

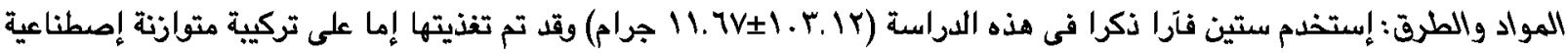

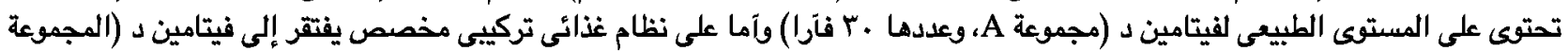

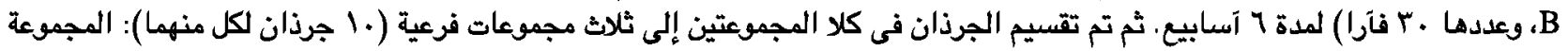

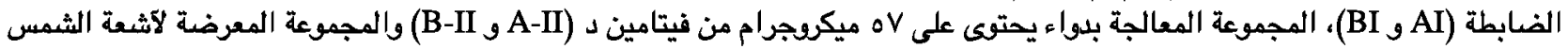

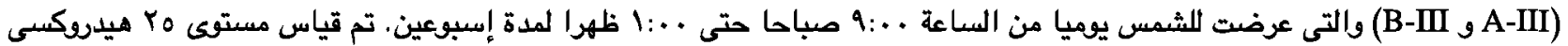

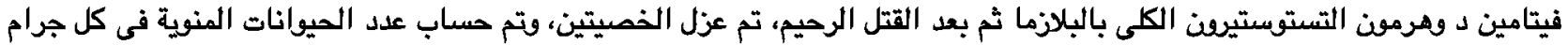

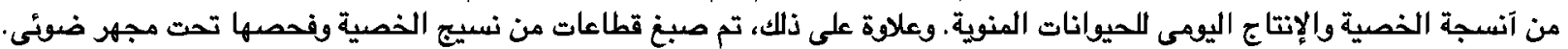

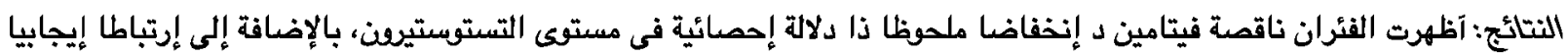

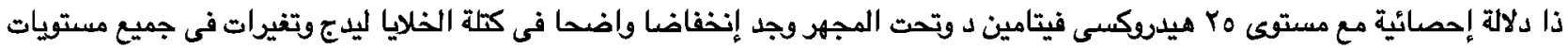

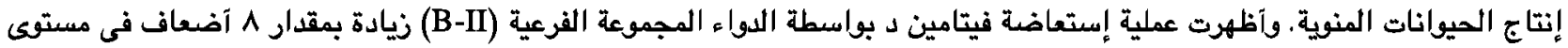

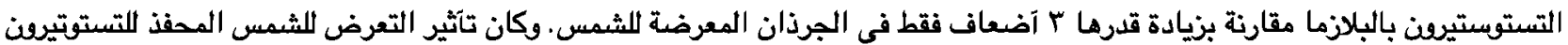

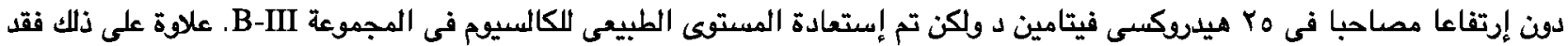

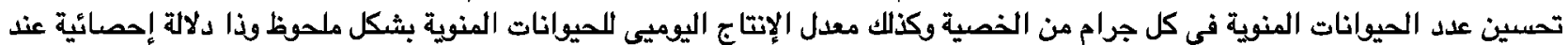

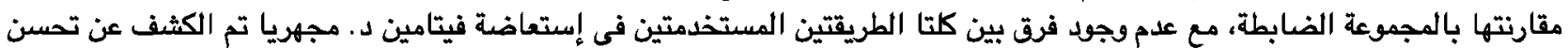

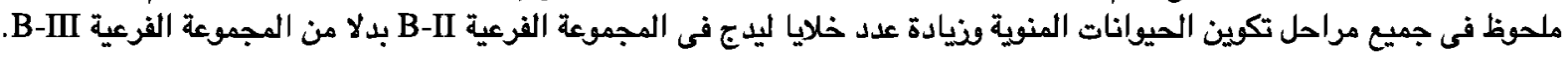

الخلاصة: للآلوية التى تحتوى على فيتامين د يمكن آن تزيد مستويات التستوستيرن فى البلازما وتحسن بنية الخصيتين بشكل آفضل آلتصل

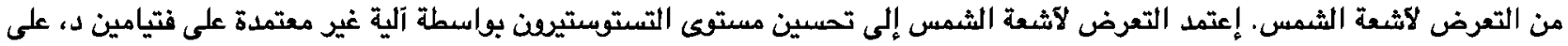
الآرجح عن طريق تصسين مستوى الكالسيوم. البحوث المستقبلية يجب آن تحقق في تلك الآلآليات. 